\title{
Erratum to: Primate seed dispersal leaves spatial genetic imprint throughout subsequent life stages of the Neotropical tree Parkia panurensis
}

\author{
Ronald Bialozyt • Kathrin Luettmann • \\ Inga M. Michalczyk • Pedro Pablo Pinedo Saboya • \\ Birgit Ziegenhagen $\cdot$ Eckhard W. Heymann
}

Published online: 21 February 2015

(c) Springer-Verlag Berlin Heidelberg 2015

\section{Erratum to: Trees (2014) 28:1569-1575}

\section{DOI 10.1007/s00468-014-1061-7}

Unfortunately, in the original publication of this article, all dots in Fig. 1c were drawn black, which suggests significant values. However, only the value for the Distance class $100 \mathrm{~m}$ is significant and should be black. The corrected figure is given below:

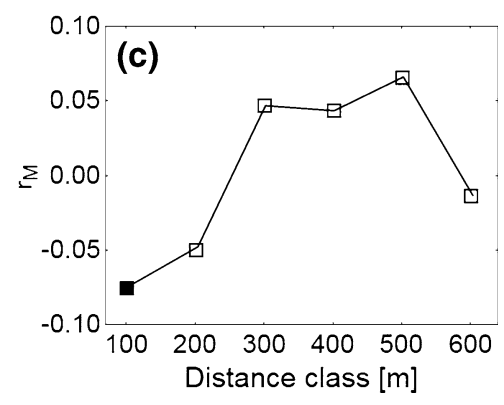

The online version of the original article can be found under doi:10.1007/s00468-014-1061-7.

R. Bialozyt · I. M. Michalczyk · B. Ziegenhagen AG Naturschutzbiologie, Philipps-Universität Marburg,

Karl-von-Frisch-Straße 8, 35043 Marburg, Germany

K. Luettmann · E. W. Heymann $(\bowtie)$

Abt. Verhaltensökologie \& Soziobiologie, Deutsches

Primatenzentrum (DPZ), Kellnerweg 4, 37077 Göttingen,

Germany

e-mail: eheyman@gwdg.de

Present Address:

I. M. Michalczyk

Scratch Pharmacovigilance GmbH, Färbgasse 24,

35510 Butzbach, Germany

P. P. P. Saboya

Facultad de Ciencias Forestales, Universidad Nacional de La

Amazonía Peruana (UNAP), Pevas 5ta cdra., Iquitos, Peru 